\title{
MacroBen integrated database on benthic invertebrates of European continental shelves: a tool for large-scale analysis across Europe
}

\author{
E. Vanden Berghe ${ }^{1,2, *}$, S. Claus, W. Appeltans, S. Faulwetter, C. Arvanitidis, P. J. Somerfield, \\ I. F. Aleffi, J. M. Amouroux, N. Anisimova, G. Bachelet, S. J. Cochrane, M. J. Costello,
} J. Craeymeersch, S. Dahle, S. Degraer, S. Denisenko, C. Dounas, G. Duineveld, C. Emblow, V. Escaravage, M. C. Fabri, D. Fleischer, A. Grémare, M. Herrmann, H. Hummel, I. Karakassis, M. Kędra, M. A. Kendall, P. Kingston, L. Kotwicki, C. Labrune, J. Laudien, E. L. Nevrova, A. Occhipinti-Ambrogi, F. Olsgard, R. Palerud, A. Petrov, E. Rachor, N. Revkov, H. Rumohr, R. Sardá, W. C. H. Sistermans, J. Speybroeck, U. Janas, G. Van Hoey, M. Vincx, P. Whomersley, W. Willems, M. Włodarska-Kowalczuk, A. Zenetos, M. L. Zettler, C. H. R. Heip

${ }^{1}$ Flanders Marine Institute, Wandelaarkaai 7, 8400 Oostende, Belgium

${ }^{2}$ Present address: IOBIS Secretariat, Institute of Marine and Coastal Sciences, Rutgers University, 71 Dudley Road, New Brunswick, New Jersey 08901, USA

\begin{abstract}
We describe an integrated database on European macrobenthic fauna, developed within the framework of the European Network of Excellence MarBEF, and the data and data integration exercise that provided its content. A total of 44 datasets including 465354 distribution records from soft-bottom macrobenthic species were uploaded into the relational MacroBen database, corresponding to 22897 sampled stations from all European seas, and 7203 valid taxa. All taxonomic names were linked to the European Register of Marine Species, which was used as the taxonomic reference to standardise spelling and harmonise synonymy. An interface was created, allowing the user to explore, subselect, export and analyse the data by calculating different indices. Although the sampling techniques and intended use of the datasets varied tremendously, the integrated database proved to be robust, and an important tool for studying and understanding large-scale long-term distributions and abundances of marine benthic life. Crucial in the process was the willingness and the positive data-sharing attitude of the different data contributors. Development of a data policy that is highly aware of sensitivities and ownership issues of data providers was essential in the creation of this goodwill.
\end{abstract}

KEY WORDS: Macrofauna $\cdot$ Biogeography $\cdot$ Integrated database $\cdot$ Data management $\cdot$ Data rescue

\section{INTRODUCTION}

Often marine biological data are the result of projects with a limited temporal and spatial cover (Floen et al. 1993). Taken in isolation, datasets resulting from these projects are only of limited use in the interpretation of large-scale phenomena. More specifically, they fail to be informative on a scale commensurate with the problems of global change that humankind is confronted with (Costello \& Vanden Berghe 2006). Individual studies are restricted in the amount of data they can generate; but by combining the results from many studies, massive databases can be created that make analyses on a much-enhanced scale possible (Grassle 2000). 
Such data have never been of greater importance considering the recent observation of major shifts of marine species due to global change. A recent report from the Marine Board of the European Science Foundation shows clear evidence of northward migrations of several marine-species populations from European seas (Philippart et al. 2007). Increasingly, vast thematic databases are being created, made possible by advances in computer technology. The Ocean Biogeographic Information System (OBIS), the data-integration component of the Census of Marine Life (CoML), assesses and explains the diversity and distribution of marine life through a network of linked databases (Grassle 2000). The Marine Biodiversity and Ecosystem Functioning (MarBEF) initiative includes implementation and networking of large-scale biodiversity research in Europe; part of this forms a contribution to the OBIS network through its European node, EurOBIS. Within the MarBEF working group Global Patterns of Marine Biodiversity across Ecosystems (Theme 1), an integrated database (MacroBen) on soft-bottom macrobenthos was compiled. The present paper describes the content, data integration, standardisation and functionalities of the MacroBen database.

\section{CONSTITUENT DATASETS}

Each dataset (Table 1) was archived and described in detail at the data centre of the Flanders Marine Institute (VLIZ). Describing datasets in a standardised way made it possible to create a searchable metadata inventory, thus facilitating data discovery and sharing. These metadata include information needed to decide on the relevance of a dataset in a particular context, e.g. where and when the data were collected, what the intended use of the dataset was, how data were collected, who played a role in the collection and the management of the data, where the data are stored and in what format and under which conditions they are available. All metadata descriptions are publicly available through the MarBEF website (www.marbef. org/data/dataset.php). Archiving the datasets prevents them from being lost by ensuring the long-term integrity of the data. The Integrated Marine Information System (IMIS), the metadata system maintained by VLIZ (Cattrijsse et al. 2006), was used as a tool for metadata management; this system is also used to manage information on behalf of the MarBEF network.

A unique citation, brief explanation of the original dataset objective and derived publications from each of the contributing datasets are listed in Appendix 1, together with a link to the extended metadata description available in IMIS. In Appendix 1, we also propose a standard dataset citation including title, dataset collector(s) or custodian(s) (equivalent to author[s] or editor[s]), dataset owner (equivalent to publisher) and final year of sampling. We hope that this standard citation, or an equivalent one, will stimulate formal recognition of data sources in future re-use of the data.

\section{DATA INTEGRATION}

The MacroBen database integrates datasets on softbottom macrobenthic fauna from all European seas. A total of 44 datasets was collected, harmonised and integrated into a relational Access database. The integrated database includes both quantitative and qualitative data on organisms and several abiotic parameters ranging from the northeast Atlantic and the North Sea, Norwegian Sea and Arctic Ocean, the Baltic Sea and the Mediterranean and Black seas.

One of the main difficulties in integrating and comparing different datasets from various data providers is the harmonisation of the data; 3 types of harmonisation were performed: (1) taxonomic, (2) geographical, and (3) sampling methodology. All geographical coordinates were converted to decimal degrees. All datasets in which information on the datum was available used the WGS84 coordinate system. We assumed that this was also the case for those datasets where this information was missing.

Taxonomic names as recorded in the constituent datasets were matched with the European Register of Marine Species (ERMS). This authoritative taxonomic register provides a list of species occurring in the European marine environment, defined as up to the strandline or splash zone above the high-tide mark and down to 0.5 salinity (Costello et al. 2001). Spelling mistakes were corrected, information on gender and life stage removed and stored in the appropriate fields, and the taxonomic name as recorded in the dataset was linked to the name as included as valid in the ERMS. Many names in the constituent datasets proved to be omissions in the ERMS, and were, in consultation with the ERMS taxonomic editors, subsequently added to the ERMS. A further description of the ERMS can be found in Cuvelier et al. (2006), and on the MarBEF website (www.marbef.org/data/erms).

Various sampling tools and methods were used over the different datasets. About $50 \%$ of the data was derived from sampling with Van Veen grabs. To a lesser extent the data were derived from sampling with a Smith-McIntyre, Ponar or APN grab, cores or other hand-operated devices. Two datasets provided data from museum collections. Overall, $33 \%$ of the data were qualitative in nature, while $30 \%$ contained not only specimen counts but also biomass data (Table 2). The sampling area from the quantitative datasets 
Table 1. Datasets included in the MacroBen database with 2-letter station code. The ID refers to the metadata of the datasets stored in the Register of Resources

\begin{tabular}{|c|c|c|c|c|c|c|}
\hline ID & Code & Dataset & Geographical area & $\begin{array}{l}\text { Total no. } \\
\text { of records }\end{array}$ & $\begin{array}{l}\text { Total no. } \\
\text { of stations }\end{array}$ & $\begin{array}{l}\text { Temporal } \\
\text { cover }\end{array}$ \\
\hline \multicolumn{7}{|c|}{ North Sea and northeast Atlantic Ocean } \\
\hline 345 & bi & BioMar survey of Ireland & Irish coastal zone & 86359 & 2397 & $1972-1996$ \\
\hline 1600 & o5 & BIOMÔR 1 dataset & Southern Irish, Celtic seas & 5166 & 51 & $1989-1991$ \\
\hline 615 & $\mathrm{np}$ & National Marine Monitoring Programme & $\begin{array}{l}\text { North Sea, English Channel } \\
\text { Celtic Sea }\end{array}$ & 1161 & 40 & $2002-2003$ \\
\hline 534 & $\mathrm{pl}$ & Plymouth Sound dataset & Plymouth Sound, English Channel & 1343 & 44 & 1995 \\
\hline 597 & ba & Benthos Gironde Estuary & Gironde Estuary, Biscay & 3019 & 13 & $1979-2004$ \\
\hline 599 & ni & BIS dataset of SW Netherlands (1985-2004) & $\begin{array}{l}\text { Southern part of Dutch continen- } \\
\text { tal shelf, North Sea }\end{array}$ & 136677 & 15564 & $1974-2005$ \\
\hline 633 & ug & MacroDat Belgium & Belgian part of North Sea & 33995 & 1801 & $1977-2003$ \\
\hline 67 & ns & North Sea Benthos Survey & North Sea & 11820 & 231 & $1985-1986$ \\
\hline 999 & o3 & $\begin{array}{l}\text { Offshore reference stations, North/ } \\
\text { Norwegian seas }\end{array}$ & North Sea & 9904 & 30 & $1990-2002$ \\
\hline \multicolumn{7}{|c|}{ Norwegian Sea and Arctic Ocean } \\
\hline 997 & o4 & $\begin{array}{l}\text { Offshore reference stations, Norwegian/ } \\
\text { Barents seas }\end{array}$ & $\begin{array}{l}\text { North Sea, Norwegian Sea, } \\
\text { Barents Sea }\end{array}$ & 59710 & 184 & $1991-2001$ \\
\hline 243 & hs & Polish Arctic Marine Programme & Spitsbergen, Greenland Sea & 603 & 34 & 2002 \\
\hline 614 & ko & $\begin{array}{l}\text { Soft bottom community structure and } \\
\text { diversity in Arctic Kongsfjorden }\end{array}$ & Spitsbergen, Greenland Sea & 210 & 6 & 2003 \\
\hline 533 & ar & Arctic soft-sediment macrobenthos & Barents Sea and Arctic Ocean & 1005 & 22 & 1991 \\
\hline 998 & 06 & Offshore reference stations, Finnmark & Norwegian, Barents seas & 11898 & 53 & $1998-2000$ \\
\hline 12 & o2 & Northern Barents Sea 1992 & Barents Sea & 1919 & 10 & 1992 \\
\hline 11 & 08 & Benthic fauna around Franz Josef Land & Barents Sea & 2630 & 9 & 1992 \\
\hline 461 & 07 & Benthic fauna around Pechora Sea & Barents Sea & 2964 & 15 & 1992 \\
\hline \multicolumn{7}{|c|}{ Skagerrak and Baltic Sea } \\
\hline 601 & ze & $\begin{array}{l}\text { Macrozoobenthos Baltic Sea (1980-2005) } \\
\text { as part of IOW Monitoring }\end{array}$ & Baltic Sea & 3589 & 19 & $1980-2005$ \\
\hline 611 & $\mathrm{pu}$ & Bay of Puck dataset & Baltic Sea & 539 & 29 & 1996 \\
\hline 612 & $\mathrm{gd}$ & Gulf of Gdansk dataset & Baltic Sea & 87 & 13 & 1995-2002 \\
\hline 617 & n3 & N3 data of Kiel Bay & Baltic Sea & 8944 & 1 & 1986-2004 \\
\hline 618 & 70 & Kiel Bay intercalibration dataset & Baltic Sea & 1144 & 1 & 1995 \\
\hline 11 & of & Oslofjord 93-94 & Skaggerak & 1469 & 34 & 1993-1994 \\
\hline 618 & of & Oslofjord 96-97 & Skaggerak & 1096 & 23 & $1996-1997$ \\
\hline \multicolumn{7}{|c|}{ Mediterranean and Black Sea } \\
\hline 603 & bl & Soft Bottom of the Bay of Blanes & Balearic Sea & 3754 & 2 & 1992-1997 \\
\hline 213 & gr & Redit dataset & Western Mediterranean & 5642 & 92 & 1998 \\
\hline 597 & $\mathrm{fb}$ & Fauna Bentonica dataset & Adriatic Sea & 2418 & 380 & $1934-1936$ \\
\hline 602 & $\operatorname{lm}$ & LBMRev dataset & Adriatic Sea & 9321 & 28 & 1985-2004 \\
\hline 600 & $\mathrm{OC}$ & Cesenatico dataset & Adriatic Sea & 963 & 1 & $1996-2002$ \\
\hline 630 & o1 & Northern Aegean dataset & Aegean, Ionian seas & 7277 & 419 & 1937 \\
\hline 595 & ap & Aegean polychaetes dataset & Aegean Sea & 2215 & 70 & $1937-2000$ \\
\hline 613 & ka & $\begin{array}{l}\text { Cretan shelf macrofauna and macro- } \\
\text { fauna of Greek polluted sites }\end{array}$ & Aegean, Ionian seas & 11861 & 199 & $1986-1997$ \\
\hline 598 & do & Mop Crete dataset & Aegean Sea & 2670 & 56 & 1988 \\
\hline 622 & M2 & $\begin{array}{l}\text { Aegean Sea coastal benthic communities, } \\
\text { Geras Gulf (Mytilini) }\end{array}$ & Aegean Sea & 4634 & 9 & $1986-1988$ \\
\hline 289 & M3 & Seasonal zoobenthos, Saronikos & Aegean Sea & 2050 & 6 & $1989-1990$ \\
\hline 623 & M6 & Kalamitsi dataset & Ionian Sea & 2037 & 22 & $1990-1991$ \\
\hline 624 & M7 & Kerkyra dataset & Ionian Sea & 1015 & 12 & 1991-1992 \\
\hline 625 & M8 & Zoobenthos Kyklades, Aegean Sea dataset & Aegean Sea & 882 & 14 & 1986 \\
\hline 272 & M0 & Gialova 1 & Aegean, Ionian seas & 1216 & 7 & 1995-1996 \\
\hline 626 & M1 & MegFeod-Black Sea dataset - IBSS, Sevastopol & Black Sea & 169 & 24 & 1986 \\
\hline 627 & M4 & Strelbay-Black Sea dataset - IBSS, Sevastopol & Black Sea & 297 & 18 & 1993 \\
\hline 628 & M5 & Yalta-Black Sea dataset - IBSS, Sevastopol & Black Sea & 308 & 26 & $1979-1986$ \\
\hline 629 & M9 & Laspibay-Black Sea dataset - IBSS, Sevastopol & Black Sea & 689 & 33 & 1996 \\
\hline 490 & bo & Biocean dataset & $\begin{array}{l}\text { Atlantic, Arctic, Baltic, } \\
\text { Mediterranean seas }\end{array}$ & 18685 & 1071 & $1967-2001$ \\
\hline
\end{tabular}


ranged from 0.008 to $1.2 \mathrm{~m}^{2}$ with $0.1 \mathrm{~m}^{2}$ being the most common. In $23 \%$ of the distribution records, replicate samples were taken.

\section{CONCEPTUAL MODEL}

The structure and concept of the MacroBen database and data management was based on an earlier system, created for a similar initiative: the North Sea Benthos Project 2000 (NSBP), an activity of ICES (Rees et al. 2007). In the NSBP initiative, data from the North Sea from various sources was brought together and analysed jointly. The data management for the NSBP was described in Vanden Berghe et al. (2007). The data management of both NSBP and MacroBen is based on a series of Access databases: 1 for each constituent dataset, and 1 to contain the integrated data. The latter also contains tools and a simple user interface to work with the data. At any point, the integrated data could be recompiled from the individual databases. This system made it possible to manage the data from individual datasets separately, and go through an iterative process of data cleaning and harmonisation. The structure of the Access databases containing the individual datasets depended on the formats employed by the data providers, and will not be discussed further here. Each of these individual databases contained a query that wrote a standard table that was then available for the integrator Access file to read.

The basic structure of the integrator database (Fig. 1) is based on a relatively limited number of tables: distribution records, taxonomic information, georeferenced sampling stations, abiotic data and metadata. Since the data were not edited in this database, no attempt was made at complete normalisation; the normalisation was done at the level of the Access databases containing the constituent datasets. Before analysis, the data structure was even further simplified, to a single flat table. This way, users were not forced to study the structure of the database before analysing the data. It also made export of the data to other programs such as spreadsheets trivial.

Both qualitative and quantitative distribution records were integrated into the distribution record (dr) table. This table stores the station name and a unique station code, code of the replicate sample, latitude and longitude, date, depth, surface area sampled, sampling depth, sediment type, mesh size, count and biomass, life stage, the original dataset code $(\mathrm{db})$, a code for the standardised species name (aphiaID) and a free note. Species name, latitude and longitude, and a description of the origin of the data were the only mandatory fields; but extra information was available for many of the constituent datasets.
Table 2. Sampled area and equipment used over the different datasets. na = not applicable

\begin{tabular}{|c|c|c|}
\hline Code & Area $\left(\mathrm{m}^{2}\right)$ & Equipment \\
\hline bi & $\begin{array}{l}\text { na } \\
\text { (qualitative data) }\end{array}$ & $\begin{array}{l}\text { Direct observation on seashores } \\
\text { and by SCUBA divers }\end{array}$ \\
\hline o5 & 0.1 & Van Veen grab \\
\hline $\mathrm{np}$ & 0.1 & Day grab \\
\hline $\mathrm{pl}$ & 0.008 & Diver-operated cores \\
\hline ba & Variable & $\begin{array}{l}\text { Several (hand-corer [intertidal] } \\
\text { and Smith-McIntyre grab } \\
\text { [subtidal], suction grab and } \\
\text { quantitative Sanders sledge) }\end{array}$ \\
\hline ni & Variable & $\begin{array}{l}\text { Several (cores, box-corer, Van } \\
\text { Veen grabs, Flushing sampler) }\end{array}$ \\
\hline ug & 0.1026 and 1.2 & Van Veen grab \\
\hline ns & Variable & Van Veen grab \\
\hline o3 & 0.1 & $\begin{array}{l}\text { Modified Van Veen grab (APN } \\
\text { grab, patent Akvaplan-niva) }\end{array}$ \\
\hline o4 & 0.1 & $\begin{array}{l}\text { Modified Van Veen grab (APN } \\
\text { grab, patent Akvaplan-niva) }\end{array}$ \\
\hline hs & 0.1 & Van Veen grab \\
\hline ko & 0.2 & $\begin{array}{l}\text { Diver-operated airlift } \\
\text { system/corer }\end{array}$ \\
\hline ar & 0.1 & Box-corer \\
\hline o6 & 0.1 & $\begin{array}{l}\text { Modified Van Veen grab (APN } \\
\text { grab, patent Akvaplan-niva) }\end{array}$ \\
\hline $\mathrm{o} 2$ & 0.1 & Van Veen grab \\
\hline 08 & 0.1 & Van Veen grab \\
\hline 07 & 0.1 & Van Veen grab \\
\hline $\mathrm{ze}$ & 0.1 & $\begin{array}{l}\text { Van Veen grab, dredge with } \\
5 \mathrm{~mm} \text { mesh size (qualitative) }\end{array}$ \\
\hline $\mathrm{pu}$ & 0.01 & Eckman grab \\
\hline gd & 0.1 & Van Veen grab \\
\hline n3 & 0.1 & Van Veen grab \\
\hline 70 & 0.1 & Van Veen grab \\
\hline of & 0.1 & Van Veen grab \\
\hline of & 0.1 & Van Veen grab \\
\hline bl & 0.06 & Van Veen grab \\
\hline gr & 0.1 & Van Veen grab \\
\hline $\mathrm{fb}$ & 0.1 and 0.2 & Petersen dredge \\
\hline $\operatorname{lm}$ & 0.1 & Van Veen grab \\
\hline oC & 0.24 & Van Veen grab \\
\hline o1 & Variable & Variable (museum collection) \\
\hline ap & Variable & Variable (museum collection) \\
\hline ka & 0.1 and 0.035 & Smith-McIntyre grab/core \\
\hline do & 0.1 & Smith-McIntyre grab \\
\hline M2 & 0.045 & Van Veen grab, hand-operated \\
\hline M3 & 0.05 & Ponar grab \\
\hline M6 & 0.05 and 0.1 & $\begin{array}{l}\text { Several (Ponar grab, Smith- } \\
\text { McIntyre and Veen grab) }\end{array}$ \\
\hline M7 & 0.2 & Van Veen grab, hand-operated \\
\hline M8 & 0.1 & $\begin{array}{l}\text { Smith-McIntyre sampler, hand- } \\
\text { operated }\end{array}$ \\
\hline M0 & 0.05 & Van Veen grab, hand-operated \\
\hline M1 & 0.25 & 'Ocean' grab \\
\hline M4 & 0.08 & Van Veen grab, hand-operated \\
\hline M5 & 0.25 & ‘Ocean' grab \\
\hline M9 & 0.04 & Van Veen grab \\
\hline bo & $\begin{array}{l}\text { na } \\
\text { (qualitative data) }\end{array}$ & Variable \\
\hline
\end{tabular}




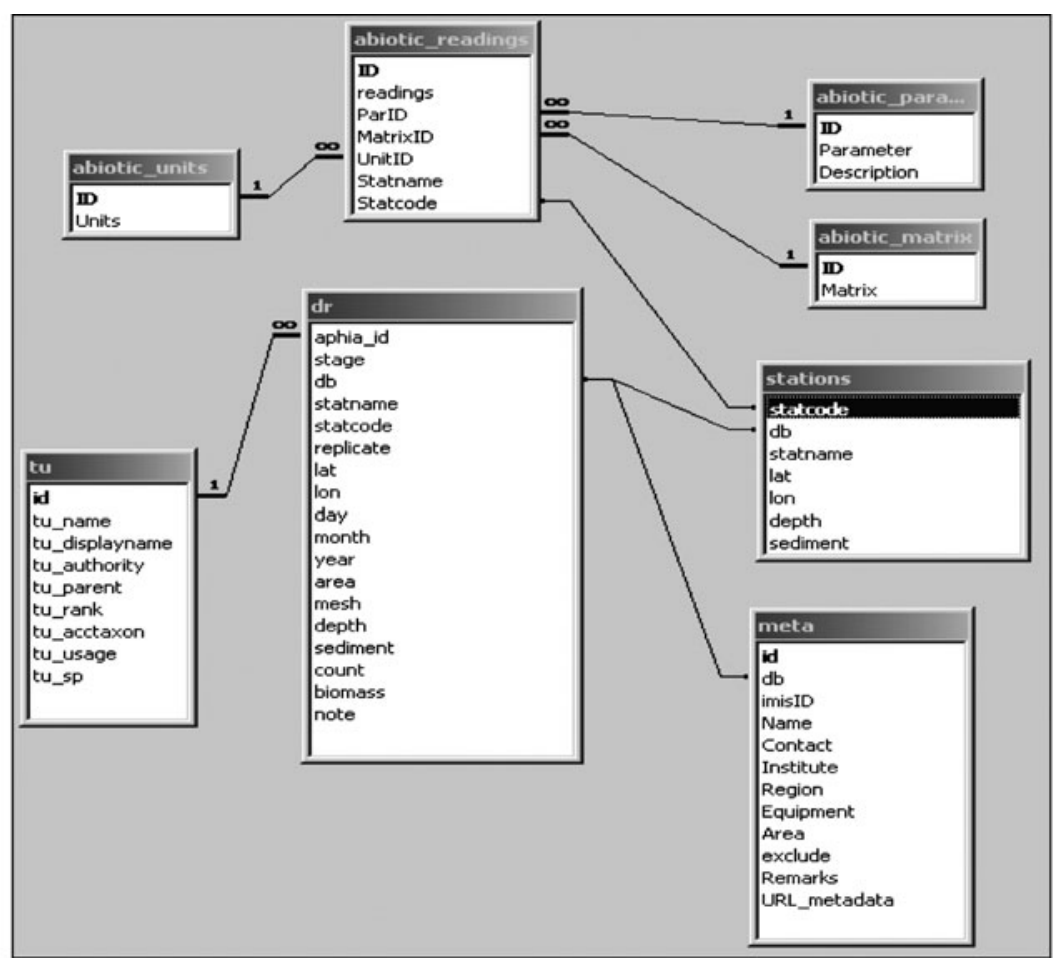

Fig. 1. Relational structure of the MacroBen database. Most table names and field names are self-explanatory; dr - distribution records; tu - taxonomic units; id - unique identifier for a record in that table. Lines show the relationships between the tables, with ' 1 ' and infinity signs indicating that one record in the first table can have many related records in the second table (e.g. one taxonomic unit has many distribution records)

A snapshot of ERMS was included in the MacroBen database, in the taxonomic unit (tu) table. The classification that is included in ERMS was used to create mechanisms to combine taxa into taxa of higher rank and to calculate several taxonomic variance measurements (Vanden Berghe 2006).

Abiotic variables measured at the stations, such as temperature, salinity and sediment type, were standardised and are stored in the table abiotic_readings. The measured parameters, the matrix and the units are stored in the tables abiotic_parameters, abiotic_matrix and abiotic_units.

The descriptive metadata of the different datasets are stored in the table called meta and linked with the biogeographical information through the unique dataset code $(\mathrm{db})$. In the meta table, information was recorded that was essential for the interpretation of the data, especially information on sample sizes and methodology. Table 1 gives an overview of the datasets included in MacroBen, and was created on the basis of a report extracted from IMIS. Unique identifiers for each of the datasets are listed in the table, and can be used to find the relevant record in IMIS.

The database interface can be made available upon request, for similar initiatives, or to re-utilise some of the coding to calculate the biodiversity measures. The Manuela Project, part of MarBEF, made use of the same database structure and tools (Vandepitte et al. 2007). Future work within Theme 1 of MarBEF will also make use of the system.

\section{FUNCTIONALITIES}

An interface was built on the integrated database, allowing users to manipulate data prior to analysis and allowing subselection of data at the level of dataset, species, or individual distribution records (Fig. 2).

The MacroBen database stores a set of built-in functions for calculation of taxonomic and diversity indices. Various options can be chosen for subselecting part of the data for analysis, such as the inclusion or exclusion of several datasets, selecting only the qualitative or quantitative data, only observations on adult specimens, restricting the data to a single taxonomic group or an identification rank or excluding manually non-macrobenthic taxa. Temporal or spatial selections can also be made. By indicating the proportion of samples in which a taxon has to be present and the minimum number of individuals in a sample to force the species to be present, rare species can be excluded from the selection. Excluding rare species has the effect of reducing the data matrix to a more manageable size (depending on the analytical objectives); it also minimises the effects of rare, possibly vagrant species, on the analysis (Gray 1981). Though the facility to conduct such filtering was considered important, the use of this feature is not necessarily recommended: modern computers and software are able to handle large matrices; a suitable choice of algorithms should make sure that the analysis demonstrates main effects, rather than those resulting from chance encounters of rare species.

The interface facilitates pooling of records using different criteria: replicates, taxonomy and life stages. For taxonomy, there were different lumping strategies: species level, genus level, family level, valid taxon or original name. The species-level lumping strategy keeps the highest taxonomic precision but sample size will decrease, since all incomplete identifications will be discarded. Aggregating records at genus or family level will decrease the taxonomic precision but will allow the inclusion of records only identified to genus or family, 


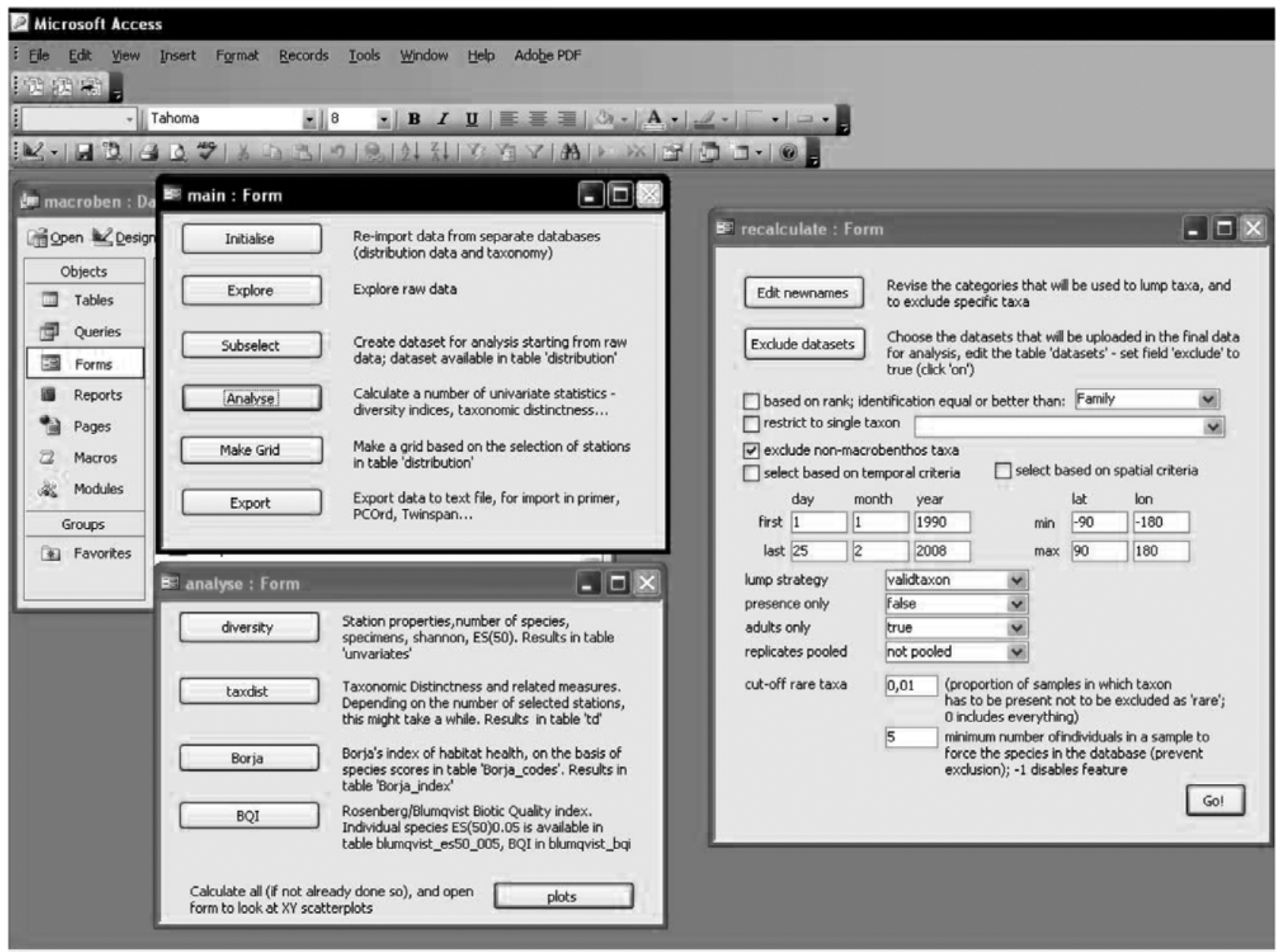

Form View

Fig. 2. User interface of the MacroBen database

respectively, thus increasing the number of records available for analysis. The main reason to include the taxonomic lumping was to increase the robustness of the conclusions based on the analysis. Aggregating to a higher taxonomic level has the advantage that resulting analyses become more robust, and less dependent on the potential problems posed by differences in identifications by different research groups.

After selection of the data for inclusion and pooling strategies, an intermediate table with density values (ind. $\mathrm{m}^{-2}$ ) will be created, from which a variety of frequently used diversity and taxonomic indices can be calculated such as: (1) the Shannon-Wiener diversity index (Magurran 1998), (2) the Hurlbert diversity index calculated for 50 individuals, $\mathrm{E}\left(\mathrm{S}_{50}\right)$ (Hurlbert 1971), (3) the Biotic Quality Index (Rosenberg et al. 2004), (4) AMBI indices of habitat health (Borja et al. 2000, 2003) and (5) taxonomic distinctness coefficients and related measures (Hurlbert 1971, Clarke \& Warwick 1998, 1999, 2001). A graphic interface of the database allows 2-dimensional plotting of the calculated indices.
The different stations used in the selection can be projected (converted from latitude and longitude to distance in $\mathrm{m}$ north and east from a reference point) using the Lambert Azimuthal Equal Area or the Azimuthal Equidistant projection. This allows calculating distances between positions of stations, and aggregating data in grid cells, with the size of the cells controlled by the user.

After selection, calculation of the different indices and projection, the MacroBen database allows export of the species $\times$ Station matrix to a delimited text file, which can be imported into additional statistical analysis software, such as TWINSPAN (Hill 1979) or PRIMER (Clarke \& Warwick 2001). Both density and count data can be exported; densities are scaled to $1 \mathrm{~m}^{2}$ and counts are the actual number of specimens counted. Possible export file types are in condensed format (.con), which can be imported in the TWINSPAN package, an ASCII tabdelimited list (e.g. PCOrd) or an ASCII tab-delimited table (e.g. PRIMER). Another possible export is the taxonomic hierarchy, which can be used as an aggregation file in PRIMER. 


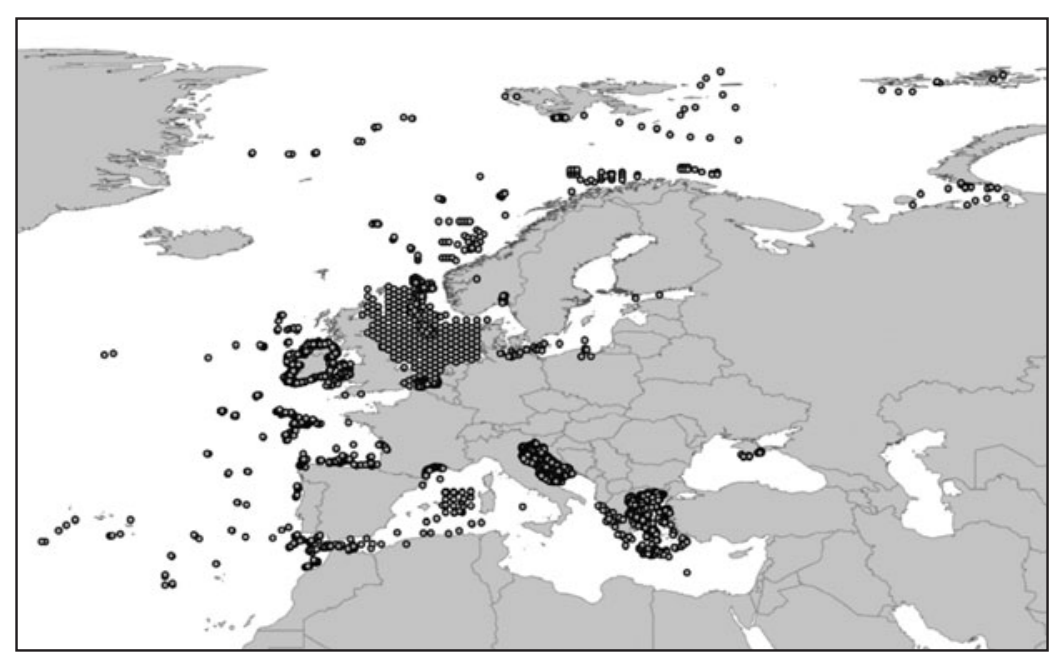

Fig. 3. Distribution map of the sampling stations of the integrated MacroBen database

\section{CONTENT OF THE DATABASE}

The MacroBen database contains data from 1937 to 2005 from different research and monitoring programmes and includes 22897 sampled stations and 465354 distribution records (Table 1). Depth is available for 416312 distribution records $(86 \%)$. There are 7481 taxa, of which 7203 were valid. The database contains 40766 abiotic readings from 75 different parameters from both the sediment and water; 46 datasets provided by 24 European institutes were collected and integrated into the MacroBen database. The samples range geographically from $32^{\circ} 2^{\prime} 48^{\prime \prime} \mathrm{N}$ to $81^{\circ} 27^{\prime} \mathrm{N}$ and from $42^{\circ} 55^{\prime} 1^{\prime \prime} \mathrm{W}$ to $58^{\circ} 56^{\prime} 35^{\prime \prime}$ 'E (Fig. 3).

The North Sea and northeast Atlantic region has the highest sampling density. Datasets from the Belgian part of the North Sea and the southern part of the Dutch continental shelf account for $37 \%$ of the total biotic records, while $<0.05 \%$ of the total records in MacroBen are from the Skagerrak and Baltic Sea region. It is essential to allow for these strongly unequal sampling densities across the different geographical regions in evaluating the ecological basis for any observed patterns.

\section{DATA POLICY}

All data stored in the MacroBen database are subject to the declaration of mutual understanding for data sharing within MarBEF Theme 1. The policy implies that the participating institutes, organisations and/or the collector of the dataset remain owners of their contributed dataset, and in control of the conditions under which datasets can be used by a third party. Metadata, as an essential tool for data discovery, is publicly available for all datasets, and includes the conditions of use. A description of the process that led to the policy, as well as a more complete description of the policy itself, is given in the introduction to this Theme Section. (Somerfield et al. 2008).

\section{CONCLUSION}

Probably the most challenging aspect in creating an integrated database is to convince data owners or custodians to contribute data. A relationship based on trust between data manager and data owner is therefore essential. Through networking activities (MarBEF Network of Excellence) at the European scale, an unambiguous data policy stating the restrictions and future use of data was drafted. Part of the discussions on the data policy and terms of use of the data consisted of a discussion of what the future availability of the data should be. It was agreed to make at least presence/absence data available as soon as a first round of papers based on the combined database was published. Data would be published through EurOBIS (www.marbef.org/data/eurobis), one of the activities of the MarBEF network. From there, the data would be available for inclusion in the International Portal of OBIS (www.iobis.org) and the Global Biodiversity Information Facility (GBIF, www.gbif.org).

Compiling an integrated database on soft-bottom macrobenthic fauna is a time-consuming effort which requires sound and professional data management. However, costs are relatively low, compared to the costs (ship time, sampling, identification) of obtaining the data. A cost-comparison described by Zeller et al. (2005) indicated that recovering paper-based, archived data and then creating electronic databases is much cheaper than the actual survey itself: the price for recovery would only be 0.2 to $0.5 \%$ of the original survey costs. As analysis of these integrated data can lead to new scientific insights, data from different sources, obtained for different uses can, in combination, provide substantial added value. An important task when integrating different data is the standardisation of taxonomic, geographical and sampling information. An essential element of this standardisation is the adoption of controlled vocabularies for various aspects of the data, including sampling methodology, gazetteer and taxonomic reference lists. Ideally, these would be used by the scientist while collecting the data. Also, the scientist should be aware 
of potential re-use of the data collected; all too often raw data are discarded, or information essential to other uses of the data are not written down. In general, there is a lack of training in, and understanding of, data management issues. The curriculum of environmental sciences (and other data-intensive sciences) should include instruction in proper data management procedures, just like students are now exposed to courses in statistical analysis.

Working with an integrated database such as MacroBen has its pitfalls: combining data from different sources causes extra variability and biases. For such large databases, it might be better to aggregate some of the data, sacrificing precision for accuracy. Since identifications were done by very many different groups, it is impossible to verify whether these identifications were done consistently - this would require ring-testing, or comparable inter-comparison exercises, for which no time or resources were available. It might therefore be beneficial to work at the level of genus or even higher, rather than at the more precise but possibly inaccurate level of species. Nevertheless, the result of the MacroBen data integration was the production of a very large dataset which, with suitable adjustments for inconsistencies in the data, provided enhanced statistical power in the identification of significant patterns. Also, the larger 'footprint' of the data (i.e. the larger taxonomic, geographical and temporal cover) should, in practice, result in the presence of stronger signals in the data. This increase in power and in signal should more than compensate for any loss in precision.

Of course, integration of existing data from disparate sources will rarely match the outcome of collaborative international research and monitoring programmes in terms of precision and accuracy. In the present integrated database, distribution of the data is dictated by research needs of the individual studies, and results in strong geographical and temporal bias. Large differences in sample size and replication restrict the type of analysis that can meaningfully be applied to the data. However, integrating all available data seems to be the only way, for the time being, to build databases that are needed to inform environmental management at and above sea-wide scales. Opportunistic re-use of available data can lead to problems, but the papers in this Theme Section prove that useful insights can be gained from them.

The MacroBen database and publications are only a first step in an ongoing process. MarBEF is now integrating datasets on hard-bottom biota, and planktonic datasets; a first round of papers on an integrated database on meiofauna was published (Vandepitte et al. 2009). Eventually, these activities will demonstrate the scientific and societal value of building collaborative databases. Undoubtedly, better science would be done if all data were made publicly available after the publication of the reports and articles that refer to them. Many journals have a policy that ensures public availability of the involved datasets but in practice it seems to be poorly enforced (with the exception of genetic sequence data, which are routinely made available through GenBank). Scientists who are custodians of relevant data are urged to contact the MarBEF data management team and explore possible collaboration.

Acknowledgements. The MacroBen project was carried out in the framework of the MarBEF Network of Excellence 'Marine Biodiversity and Ecosystem Functioning' which is funded by the Sustainable Development, Global Change and Ecosystems Programme of the European Community's Sixth Framework Programme (contract no. GOCE-CT-2003-505446). This publication is contribution number MPS-09025 of MarBEF. Pieter Deckers (then at VLIZ) and Panayiotis Gotsis (HCMR) contributed to the Visual Basic code of the Access front-end. A. S. Y. Mackie, P. G. Oliver, E. I. S. Rees, A. Koukouras, The Norwegian Oil Industry Association (OLF) and Det Norske Veritas are thanked for additional data contributions.

\section{LITERATURE CITED}

Aleffi F, Bettoso N (2001) Il macrozoobenthos del litorale di Barcola (Golfo di Trieste, Nord Adriatico). Hydrores Inf 18: $7-15$

Aleffi F, Orel G, Del Piero D, Vio E (1992) Oxygen condition in the Gulf of Trieste (High Adriatic). In: Vollenweider RA, Marchetti R, Viviani R (eds) Marine coastal eutrophication. Elsevier, London, p 431-440

Aleffi F, Goriup F, Orel G, Zuccarello V (1996) Analysis of macrobenthic community structure in three areas of the Gulf of Trieste. Ann An Istrske Mediter Stud Hist Nat 9: $39-44$

Aleffi F, Bettoso N, Solis-Weiss V (2003) Spatial distribution of soft-bottom polychaetes along the western coast of the northern Adriatic Sea (Italy). Ann Ser Hist Nat 13:211-222

Arvanitidis C (2000) Polychaete fauna of the Aegean Sea: inventory and new information. Bull Mar Sci 66:73-96

Arvanitidis C, Koutsoubas D, Dounas C, Eleftheriou A (1999) Annelid fauna of a Mediterranean lagoon (Gialova Lagoon, South-West Greece): community structure in a severely fluctuating environment. J Mar Biol Assoc UK 79: 849-856

Arvanitidis C, Bellan G, Drakopoulos P, Valavanis V, Dounas C, Koukouras A, Eleftheriou A (2002) Seascape biodiversity patterns along the Mediterranean and the Black Sea: lessons from the biogeography of benthic polychaetes. Mar Ecol Prog Ser 244:139-152

Arvanitidis C, Valavanis VD, Eleftheriou A, Costello MJ and others (2006) MedOBIS: biogeographic information system for the eastern Mediterranean and Black Sea. Mar Ecol Prog Ser 316:225-230

Bachelet G (1981) Données préliminaires sur l'organisation trophique d'un peuplement benthique marin. Vie Milieu 31:205-213

Bogdanos C, Simboura N, Zenetos A (2002) The benthic fauna of Geras Gulf, (Lesvos isl. Greece): inventory, distribution and some zoogeographical considerations. Hell Zool Arch $6: 1-22$ 
Borja A, Franco J, Pérez V (2000) A marine biotic index to establish the ecological quality of soft-bottom benthos within European estuarine and coastal environments. Mar Pollut Bull 40:1100-1114

Borja A, Muxika I, Franco J (2003) The application of a marine biotic index to different impact sources affecting soft-bottom benthic communities along European coasts. Mar Pollut Bull 46:835-845

Cattrijsse A, Claus S, D'Haenens T, Haspeslagh J, T'Jampens R, Vanden Berghe E, Vandepitte L (2006) IMIS integrated marine information system input manual. Flanders Marine Institute (VLIZ), Oostende, Belgium

Clarke KR, Warwick RM (1998) A taxonomic distinctness index and its statistical properties. J Appl Ecol 35:523-531

Clarke KR, Warwick RM (1999) The taxonomic distinctness measure of biodiversity: weighting of step lengths between hierarchical levels. Mar Ecol Prog Ser 184:21-29

Clarke KR, Warwick RM (2001) A further biodiversity index applicable to species lists: variation in taxonomic distinctness. Mar Ecol Prog Ser 216:265-278

Cochrane SJ, Dahle S, Oug E, Gulliksen B, Denisenko S (1998) Benthic fauna in the Northern Barents Sea. Akvaplan-niva rep no. 434.97.1286, Norwegian Ministry of Environment, Oslo

Connor DW, Brazier DP, Dalkin MJ, Hill TO, Holt RHF, Northen KO, Sanderson WG (1999) Marine nature conservation review: marine biotope classification for Britain and Ireland, version 97.06. In: Picton BE, Costello MJ (eds) The BioMar biotope viewer: a guide to marine habitats, fauna and flora in Britain and Ireland. Environmental Sciences Unit, Trinity College, Dublin

Costello MJ, Vanden Berghe E (2006) 'Ocean biodiversity informatics': a new era in marine biology research and management. Mar Ecol Prog Ser 316:203-214

Costello MJ, Emblow CS, Picton BE (1996) Long term trends in the discovery of marine species new to science in Britain and Ireland. J Mar Biol Assoc UK 76:255-257

Costello MJ, Emblow CS, White R (eds) (2001) European register of marine species. A check-list of the marine species in Europe and a bibliography of guides to their identification. Patrimoines naturelles, 50 Museum national d'Histoire naturelle, Paris

Craeymeersch JA, Heip CHR, Buijs J (1997) Atlas of North Sea benthic infauna: based on the 1986 North Sea Benthos Survey. ICES Coop Res Rep 218. ICES, Copenhagen

Cuvelier D, Claus S, Appeltans W, Vanhoorne B, Vanden Berghe E, Costello MJ (2006) European register of marine species (ERMS - plans turning into reality! MarBEF Newsl 4:14-15

Dahle S, Denisenko S, Denisenko N, Cochrane S (1992) Benthic fauna in the Pechora Sea. Sarsia 83:183-210

Dahle S, Anisimova NA, Palerud R, Pearson TH, Matishov GG (2009) Macrobenthic fauna of the Franz Josef Land archipelago. Polar Biol 32:169-180

Degraer S, Verfaillie E, Willems W, Adriaens E, Vincx M, Van Lancker V (2008) Habitat suitability modelling as a mapping tool for macrobenthic communities: an example from the Belgian part of the North Sea. Cont Shelf Res 28: 369-379

Fabri MC, Galeron J, Maudire G (2004) BIOCEAN: a new database for deep-sea benthic ecological data. In: Vanden Berghe E, Appeltans W, Fabricius M (eds) Abstracts, Ocean Biodiversity Informatics, Hamburg, Germany, 29 Nov to 1 Dec 2004. Flanders Marine Institute (VLIZ), Oostende, Belgium, p 63

Fabri MC, Galéron J, Larour M, Maudire G (2006) Combining the Biocean database for deep-sea benthic data with the online Ocean Biogeographic Information System. Mar
Ecol Prog Ser 316:215-224

Floen S, Gjøsæter H, Korneliussen R, Sagen H, Thorvaldsen P, Wennevik V (1993) An integrated database for marine research. ICES CM 1993 (D:23 Sess.T.)

Grassle JF (2000) The Ocean Biogeographic Information System (OBIS): an on-line, worldwide atlas for accessing, modeling and mapping marine biological data in a multidimensional geographic context. Oceanography (Wash DC) 13: $5-9$

Gray JS (1981) The ecology of marine sediments: an introduction to the structure and function of benthic communities. Cambridge University Press, Cambridge

Heip C, Basford D, Craeymeersch J, Dewarumez JM and others (1992) The benthic communities of the North Sea: a summary of the results of the North Sea benthos survey. ICES Coop Res Rep 190:148-175

Herrmann M (2004) Makrozoobenthos-Gemeinschaften arktischer Weichböden: Struktur und Bedeutung als Nahrungsgrundlage demersaler Fische. MSc thesis, Christian-Albrechts-Universität, Kiel

Hill MO (1979) TWINSPAN. A FORTRAN program for arranging multivariate data in an ordered two-way table by classification of individuals and attributes. Cornell University, Ithaca, NY

Hurlbert SH (1971) The nonconcept of species diversity: a critique and alternative parameters. Ecology 52:577-586

Hyland J, Balthis L, Karakassis I, Magni P and others (2005) Organic carbon content of sediments as an indicator of stress in the marine benthos. Mar Ecol Prog Ser 295:91-103

Janas U (1998) Influence of hypoxia and hydrogen sulphide on macrofauna in the Gulf of Gdansk. PhD thesis, Gdańsk University

Kallonas M, Zenetos A, Gofas S (1999) Notes on the ecology and distribution of microbivalvia in Greek waters. Conchiglia 291:11-20

Karakassis I, Eleftheriou A (1997) The continental shelf of Crete: structure of macrobenthic communities. Mar Ecol Prog Ser 160:185-196

Karakassis I, Eleftheriou A (1998) The continental shelf of Crete: the benthic environment. PSZN I: Mar Ecol 19: 263-277

Karakassis I, Hatziyanni E (2000) Benthic disturbance due to fish farming analyzed under different levels of taxonomic resolution. Mar Ecol Prog Ser 203:247-253

- Karakassis I, Hatziyanni E, Tsapakis M, Plaiti W (1999) Benthic recovery following cessation of fish farming: a series of successes and catastrophes. Mar Ecol Prog Ser 184:205-218

- Karakassis I, Tsapakis M, Hatziyanni E, Papadopoulou KN, Plaiti W (2000) Impact of cage farming of fish on the seabed in three Mediterranean coastal areas. ICES J Mar Sci 57:1462-1471

Karakassis I, Tsapakis M, Smith CJ, Rumohr H (2002) Fish farming impacts in the Mediterranean studied through sediment profiling imagery. Mar Ecol Prog Ser 227:125-133

Kendall MA (1995) Are Arctic soft-sediment macrobenthic communities impoverished? Polar Biol 16:393-399

Kendall MA, Widdicombe S (1999) Small scale patterns in the structure of macrofaunal assemblages of shallow soft sediments. J Exp Mar Biol Ecol 237:127-140

Kisseleva MI, Revkov NK, Kopitov YP (1999) The modern state and the long-term changes of zoobenthos in Streletskaya Bay (Sevastopol area). Hydrobiol J 35 (original in Gidrobiologichesky zhurnal 1997; 33:3-13 (in Russian))

Koutsoubas D, Dounas C, Arvanitidis C, Kornilios S, Petihakis G, Triantafyllou G, Eleftheriou A (2000) Macrobenthic community structure and disturbance assessment in a Mediterranean lagoon (Gialova Lagoon, Ionian Sea). ICES J Mar Sci 57:1472-1480 
Laudien J, Herrmann M, Arntz WE (2004) Soft bottom community structure and diversity in Arctic Kongsfjord. In: Wiencke C (ed) The coastal ecosystem of Kongsfjorden, Svalbard. Ber Polarforsch 492:103-111

Mackie ASY, Oliver PG, Rees EIS (1995) BIOMÔR 1 benthic biodiversity in the Southern Irish Sea. BIOMÔR Rep 1, National Museums \& Galleries of Wales, Cardiff

Magurran AE (1998) Ecological diversity and its measurement. Chapman \& Hall, London

McGrath D, Costello MJ, Emblow C (2000) The hermit crab, Diogenes pugilator (Roux, 1829) in Irish waters. Biol Environ Proc R Ir Acad B 100:115-118

Mikhailova TV (1989) Changes by depth in distribution of benthos in Yalta region. In: Long-term changes of zoobenthos in the Black Sea. Naukova Dumka Publ, Kiev, p 18-34 (in Russian)

Mironov OG, Kiryukhina LN, Divavin IA (1992) Sanitary and biological studies in the Black Sea. S.-Pb. Hydrometeoizdat, St. Petersburg (in Russian)

> Nicolaidou A, Zenetos A, Pancucci MA, Simboura N (1993) Comparing ecological effects of two different types of pollution using multivariate techniques. PSZN I: Mar Ecol $14: 113-128$

>cchipinti-Ambrogi A, Savini D, Forni G (2005) Macrobenthos community structural changes off Cesenatico coast (Emilia Romagna, Northern Adriatic), a six-year monitoring programme. Sci Total Environ 353:317-328

Pancucci MA, Zenetos A (1990) On the echinoderm-fauna of the Geras Gulf. Acta Adriat 31:293-300

Papathanassiou E, Zenetos A (1993) A case of recovery in benthic communities following a reduction in chemical pollution in a Mediterranean ecosystem. Mar Environ Res 36:131-152

Papathanassiou E, Bogdanos C, Zenetos A (1989) Application of the log-normal distribution on the benthic communities of Geras Gulf (Mytilene, Aegean Sea). Proc 1st Conf Environmental Science and Technology, p 457-469 (in Greek)

Petrov AN (1999) Using of bioindication approach for assessment of modern anthro-pogenic impact upon coastal marine environment around Crete (the Aegean Sea) and Crimea (the Black Sea). In: Balopoulos E, et al. (eds) Oceanography of the eastern Mediterranean and the Black Sea, similarities and differences of two interconnected basins, Athens, Greece, 23-26 Feb 1999. Scientific Report, European Commission, p 396-398

Petrov AN (2000) Responses of the Black Sea macrobenthic communities upon organic enrichment impact of bottom sediments. Ecol Morya 51:45-51 (in Russian with English abstract)

Petrov AN, Revkov NK (2005) Multivariate analysis of zoobenthos structure under technogenic pollution impact (Streletskaya bay, SW Crimea). Proc Ternopol Pedagogical University, Ser Biol, Spec Issue: Hydrobiology 4: 177-180 (in Russian)

Philippart CJM (ed) (2007) Impacts of climate change on the European marine and coastal environment: ecosystems approach. ESF Marine Board Position Paper. European Science Foundation, Marine Board, Strasbourg

Pinedo S, Sarda R, Martin D (1996) Seasonal dynamics and structure of soft-bottom assemblages in the Bay of Blanes (Western Mediterranean Sea). Publ Espec Inst Esp Oceanogr 22:61-70

Pinedo S, Sarda R, Martin D (1997) Comparative study of the trophic structure of soft-bottom assemblages in the Bay of Blanes (Western Mediterranean Sea). Bull Mar Sci 60: 529-542

Rabaut M, Guilini K, Van Hoey G, Vincx M, Degraer S (2007) A bio-engineered soft-bottom environment: the impact of
Lanice conchilega on the benthic species-specific densities and community structure. Estuar Coast Shelf Sci 75: 525-536

Rees HL, Eggleton JD, Rachor E, Vanden Berghe E (2007) Structure and dynamics of the North Sea benthos. ICES Coop Res Rep 288. ICES, Copenhagen

Revkov NK (2003a) Zoobenthos regional peculiarities-modern condition of biological diversity in near-shore zone of Crimea (the Black Sea sector). Ekosi-Gidrophizika, Sevastopol, p 218-221 (in Russian)

Revkov NK (2003b) Taxonomical composition of the bottom fauna at the Black Sea Crimean coast-modern condition of biological diversity in near-shore zone of Crimea (the Black Sea sector). Ekosi-Gidrophizika, Sevastopol, p 209-218, 326-338 (in Russian)

Revkov NK, Nikolaenko TV (2002) Biodiversity of zoobenthos in the coastal zone of the south coast of Crimea (Laspi Bay area). Russ J Mar Biol 28:151-162

Revkov NK, Sergeeva NG (2004) Current state of the zoobenthos at the Crimean shores of the Black Sea. International Workshop on the Black Sea benthos, 18-23 April 2004, Istanbul, p 189-217

> Rosenberg R, Blomqvist M, Nilsson HC, Cederwall H, Dimming A (2004) Marine quality assessment by use of benthic species-abundance distributions: a proposed new protocol within the European Union Water Framework Directive. Mar Pollut Bull 49:728-739

Rumohr H, Karakassis I, Nørrevang Jensen J (2001) Estimating species richness, abundance and diversity with 70 macrobenthic replicates from the Western Baltic. Mar Ecol Prog Ser 214:103-110

Sarda R, Pindedo S, Martin D (1999) Seasonal dynamics of macroinfaunal key species inhabiting shallow soft-bottoms in the Bay of Blanes (NW Mediterranean). Acta Oecol 20: $315-326$

Sarda R, Pindedo S, Grémare A, Taboada S (2000) Changes in the dynamics of shallow soft-bottom due to man-made disturbance processes in the Catalan Western Mediterranean Sea. ICES J Mar Sci 57:1446-1457

Sergeeva NG (1992) The characteristics of the free-living nematode fauna of Yalta gulf under anthropogenic impact. In: Long-term changes of zoobenthos in the Black Sea. Naukova Dumka, Kiev, p 170-184 (in Russian)

Sergeeva NG, Mikhailova TV (1989a) Distribution and structure of bottom communities in some regions of the Southern coast of Crimea. VINITI Publ. \#1329-B89, Moscow (in Russian)

Sergeeva NG, Mikhailova TV (1989b) Distribution and structure of bottom communities in Yalta Gulf. VINITI Publ \#1328-B89, Moscow (in Russian)

Sides EM, Picton BE, Costello MJ, Crean E and others (1995) Identification and mapping of marine biotopes. In: Carroll M, Dubsky K (eds) Coastal zone management: from needs to action. Coastwatch Europe, Dublin, p 198-203

Simboura N, Zenetos A (2002) Benthic indicators to use in ecological quality classification of Mediterranean soft bottoms marine ecosystems, including a new biotic index. Mediterr Mar Sci 3:77-111

Simboura N, Zenetos A, Panayotidis P, Makra A (1995) Changes in benthic community structure along an environmental pollution gradient. Mar Pollut Bull 30:470-474

Solis-Weiss V, Rossin P, Aleffi F, Bettoso N, Orel G, Vrišer B (2001) Gulf of Trieste: sensitivity areas using benthos and GIS techniques. In: Ozhan E (ed) Proc 5th Int Conf Mediterranean Coastal Environment, MEDCOAST 01, 23-27 October 2001, Hammamet, Tunisia. Middle East Technical University, Ankara, Turkey, Vol 1-3:1567-1578

Speybroeck J, Bonte D, Gheskiere T, Grootaert P and others 
(2005) Biologische evaluatie van elf strandzones langs de Vlaamse kust, B.E.ST. Final report. Ministry of the Flemish Community, AMINAL, Nature Department, Brussels

Triantafyllou G, Petihakis G, Dounas C, Koutsoubas D, Arvanitidis C, Eleftheriou A (2000) Temporal variations on benthic communities and their behaviour to physicochemical forcing. A numerical approach. ICES J Mar Sci 57: 1507-1516

Van Aartsen JJ, Zenetos A (1987) The genus Clathromangelia Monterosato, 1884, in the Mediterranean, with the description of Clathromangelia ferhi n.sp. Conchiglia 222-223: $10-11$

> Van Hoey G, Degraer S, Vincx M (2004) Macrobenthic communities of soft-bottom sediments at the Belgian continental shelf. Estuar Coast Shelf Sci 59:599-615

Van Hoey G, Vincx M, Degraer S (2005) Small-scale geographical patterns within the macrobenthic Abra alba community. Estuar Coast Shelf Sci 64:751-763

Van Hoey G, Vincx M, Degraer S (2007) Temporal variability in the Abra alba community determined by global and local events. J Sea Res 58:144-155

Vanden Berghe E (2006) The European register of marine species: tool for data integration. In: Abstracts ICES Annu Sci Conf, 19-23 Sep 2006, Maastricht. ICES, Copenhagen, p 227

Vanden Berghe E, Rees HL, Eggleton JD (2007) NSBP 2000 data management. In: Rees HL, et al. (ed) Structure and dynamics of the North Sea benthos. ICES Coop Res Rep 288:7-20

Vandepitte L, Vanaverbeke J, Vanden Berghe E, Bezerra TC (2007) Developing an integrated database to perform joint analyses: MANUELA (Meiobenthic And Nematode biodiversity Unravelling Ecological and Latitudinal Aspects). In: Abstracts 13th Int Meiofauna Conf (THIRIMCO), $29 \mathrm{Jul}$ to 3 Aug 2007, Recife, Brazil. p 17

Vandepitte L, Vanaverbeke J, Vanhoorne B, Hernandez F, Bezerra TN, Mees J, Vanden Berghe E (2009) The MANUELA database: an integrated database on meiobenthos from European marine waters. Meiofauna Mar 17:35-60
Vatova A (1949) La fauna bentonica dell'alto e medio Adriatico. Nova Thalassia 1:1-110

Wasmund N, Pollehne F, Postel L, Siegel H, Zettler ML (2004) Biologische Zustandseinschätzung der Ostsee im Jahre 2003. Meereswiss Ber 60:1-87

> Willems W, Goethals P, Van den Eynde D, Van Hoey G and others (2008) Where is the worm? Predicting the spatial distribution of the tube-building polychaete Lanice conchilega (Pallas, 1766). Ecol Modell 212:74-79

Zeller D, Froese R, Pauly D (2005) On losing and recovering fisheries and marine science data. Mar Policy 29:69-73

Zenetos A, Papathanassiou E (1989) Community parameters and multivariate analysis as a means of assessing the effects of tannery effluents on the macrobenthos. Mar Pollut Bull 20:176-181

Zenetos A, Papathanassiou E, Van Aartsen JJ (1991) Analysis of benthic communities in the Cyclades plateau (Aegean Sea) using ecological and paleoecological datasets. PSZN I: Mar Ecol 12:123-137

Zenetos A, Bogdanos C, Simboura N (1992) Comparative study of the macrozoobenthos in the Gulfs of Geras and Kalloni. In: Proc 3rd Pan-Hellenic Symp Oceanography and Fisheries, Athens. p 548-558

Zenetos A, Simboura N, Papathanassiou E (1993) Biological indices in a volcanic area in S. Aegean (Santorini). In: Proc 4th Pan-Hellenic Symp Oceanography and Fisheries, Rhodes. p 226-229

Zenetos A, Simboura N, Panayotidis P (1994) Effects of sewage on the distribution of benthic fauna in Saronikos Gulf. UNEP MAP Tech Rep Ser 80:39-72

Zenetos A, Christianidis S, Pancucci MA, Simboura N, Tziavos CH (1997) Oceanologic study of an open coastal area in the Ionian Sea with emphasis on its benthic fauna and some zoogeographical remarks. Oceanol Acta 20: $437-451$

Zenetos A, Revkov NK, Konsulova T, Sergeeva N, Simboura N, Todorova V, Zaika VE (1999) Coastal benthic diversity in the Black and Aegean Seas. Mediterr Mar Sci 1/2: $105-117$

\section{Appendix 1. Datasets included in the MarBEF database}

Aleffi I.F., 2004: LBMRev dataset. Marine Biology Laboratory, University of Trieste, Italy.

Available at: www.marbef.org/modules.php?name=People $\& l v l=$ Data\&show $=$ html\&dasid $=602$

The primary aim for this data collection was to build a database and to apply GIS techniques in the Gulf of Trieste and North Adriatic Sea (Aleffi et al. 1992, 1996, 2003, Aleffi \& Bettoso 2001, Solis-Weiss et al. 2001). Dataset code: $\mathrm{lm}$.

Arvanitidis C., 2000: Aegean polychaetes dataset. Hellenic Centre for Marine Research, Greece.

Available at: www.marbef.org/modules.php?name=People $\& l v l=$ Data\&show $=$ html\&dasid= $=595$

The Hellenic Centre for Marine Research collected samples in the context of a number of National and EU-funded projects. The datasets provide qualitative temporal information on polychaete worms in the Aegean and Ionian Sea (Arvanitidis 2000, Arvanitidis et al. 2002, 2006). Dataset code: ap.

Bachelet G., 2004: Benthos Gironde Estuary. Université Bordeaux 1, Station Marine d'Arcachon, Laboratoire d'Océanographie Biologique, France.

Available at: www.marbef.org/modules.php?name=People
$\& l v l=$ Data $\&$ show=html\&dasid=597

The data are from 3 sources, namely the impact of dredging on benthic macrofauna (1979 data), a comparison of macrobenthos between major European tidal estuaries (1991-1992 data) and ecological monitoring of macrobenthos in an area affected by the effluents of a nuclear power plant (2004 data) (Bachelet 1981). Dataset code: ba.

Craeymeersh J.A., Kingston P., Rachor E., Duineveld G., Heip C.H.R., Vanden Berghe E., 1986: North Sea Benthos Survey.

Available at: www.marbef.org/modules.php?name=People $\& l v l=$ Data $\&$ show $=\mathrm{html} \&$ dasid $=67$

The data are the result of the 1986 North Sea Benthos Survey, an activity of the Benthos Ecology Working Group of ICES. Benthic samples were taken in a standardised way, on a regular grid covering the whole of the North Sea, and analysed by scientists from 10 laboratories. Extensive work was done to standardise taxonomy and identifications across the different laboratories (Heip et al. 1992, Craeymeersch et al. 1997). Dataset code: ns.

Dahle S., Cochrane S.J., 1992: Northern Barents Sea 1992. 
Appendix 1. (continued)

Akvaplan-niva, Norway.

Available at: www.marbef.org/modules.php?name=People \&lvl=Data\&show $=$ html $\&$ dasid $=12$

Benthic fauna in the Northern Barents Sea was mapped in July 1992 by Akvaplan-niva (Cochrane et al. 1998). Dataset code: 02 .

Dahle S., Palerud R., Anisimova N., 1992: Benthic fauna around Franz-Josef Land. Akvaplan-niva, Norway.

Available at: www.marbef.org/modules.php?name=People $\& l v l=$ Data\&show $=$ html\&dasid $=11$

Benthic fauna in the Franz-Josef Land was mapped in August 1992 by Akvaplan-niva (Dahle et al. 2009). Dataset code: o8.

Dahle S., Cochrane S.J., Denisenko S., 1992: Benthic fauna around Pechora Sea. Akvaplan-niva, Norway.

Available at: www.marbef.org/modules.php?name=People \&lvl=Data\&show $=\mathrm{html} \&$ dasid $=461$

Benthic fauna in the Pechora Sea was mapped in July 1992 by Akvaplan-niva (Dahle et al. 1992). Dataset code: o7.

Degraer S., Van Hoey G., Willems W., Speybroeck J., Vincx M., 2003: MacroDat Belgium. Macrobenthic data from the Belgian part of the North Sea from 1976 onwards. Ghent University, Biology Department, Marine Biology Section, Belgium.

Available at: www.marbef.org/modules.php?name=People $\& l v l=$ Data $\&$ show $=$ html $\&$ dasid $=633$

All data on macrobenthos of the Belgian part of the North Sea collected within several projects of the University of Ghent are integrated into this dataset. It was originally compiled to assure a proper data management of all physically separated datasets on macrobenthos (Van Hoey et al. 2004, 2005, 2007, Speybroeck et al. 2005, Rabaut et al. 2007, Van Hoey et al. 2007, Degraer et al. 2008, Willems et al. 2008). Dataset code: ug.

Dounas C., 1988: Benthos Cretan Continental Shelf. Hellenic Centre for Marine Research, Greece.

Available at: www.marbef.org/modules.php?name=People $\& l v l=$ Data $\&$ show $=$ html $\&$ dasid $=598$

This pilot benthic study was carried out during the summer of 1988 on the continental Cretan shelf (Koutsoubas et al. 1990, Karakassis \& Eleftheriou 1997, 1998). Dataset code: do.

Dounas C., 1996: Environmental impact assessment of oil pollution accident in Gialova lagoon and Navarino Bay. Hellenic Centre for Marine Research, Greece.

Available at: www.marbef.org/modules.php?name=People $\& l v l=$ Data\&show $=$ html $\&$ dasid $=272$

This dataset was part of a national project on the consequences of the Navarino oil spill in 1994 at the Gialova Lagoon, Ionian Sea (Arvanitidis et al. 1999, Koutsoubas et al. 2000, Triantafyllou et al. 2000). Dataset code: MO.

Fabri M.C., 2001: Biocean dataset. IFREMER France. Available at: www.marbef.org/modules.php?name=People $\& l v l=$ Data $\&$ show $=\mathrm{html} \&$ dasid $=490$

This dataset combines information on deep sea benthic fauna collected during several IFREMER cruises from 1967 to 2001. Due to its large geographical scope and the deep sea habitat, this dataset can be considered to some extent as an outlier of the MacroBen database (Fabri et al. 2004, 2006). Dataset code: bo.

Gray J.S., 1997: Oslofjord 96-97. University of Oslo, Norway. Available at: www.marbef.org/modules.php?name=People
$\& l v l=$ Data $\&$ show $=$ html $\&$ dasid $=1148$

Unpublished soft bottom benthic data collected in the Oslofjord within the framework of a PhD study. Dataset code: of. Grémare A., Amouroux J.M., Labrune C., 1998: Redit dataset. Observatoire Océanologique de Banyuls-Sur-Mer, Laboratoire d'Océanographie Biologique, France.

Available at: www.marbef.org/modules.php?name=People$\& l v l=$ Data \&show $=$ html $\&$ dasid= $=213$

This dataset describes the benthic macrofauna in the Gulf of Lyons. It was collected in order to assess the spatial scale of the increase of the polychaete Ditrupa arietina. Dataset code: $g r$.

Herrmann M., Laudien J., 2004: Soft bottom community structure and diversity in Arctic Kongsfjorden. AlfredWegener-Institute for Polar and Marine Research, Bremerhaven, Germany.

Available at: www.marbef.org/modules.php?name=People $\& l v l=$ Data $\&$ show $=$ html\&dasid $=614$

The data were collected as part of a diver-operated shallowwater $(5-30 \mathrm{~m})$ research study of the soft bottom benthic community in Arctic Kongsfjord/Spitsbergen (Laudien et al. 2004, Herrmann 2004). Dataset code: ko.

Hummel H., Sistermans W.C.H, Escaravage V., 2004: BIS dataset of the south-western part of Netherlands (19852004). Benthos information System, Monitor Taskforce NIOO-CEME, Netherlands.

Available at: www.marbef.org/modules.php?name=People $\& l v l=$ Data $\&$ show $=$ html $\&$ dasid= $=599$

This was the largest contributing dataset (about 130000 distribution records), over $95 \%$ of which was sourced from several Dutch monitoring programmes carried out in the Dutch Delta area (Eastern- \& Western Scheldt Estuary, Lake Grevelingen, Lake Veere) and the Dutch coastal zone (Voordelta). Dataset code: ni.

Janas U., 2002: Gulf of Gdansk dataset. University of Gdansk, Institute of Oceanography, Department of Marine Biology and Ecology, Poland.

Available at: www.marbef.org/modules.php?name=People \&lvl=Data\&show $=\mathrm{html} \&$ dasid $=612$

The datasets relate to 2 studies in the Gulf of Gdansk, one in 1995 to study the influence of hypoxia and hydrogen sulphide on the macrofauna and the other in 2002 to analyse the distribution of the macrofauna (Janas 1998). Dataset code: $g d$.

Karakassis I., 1997: Cretan shelf macrofauna and macrofauna of Greek polluted sites. Biology Department, University of Crete, Greece.

Available at: www.marbef.org/modules.php?name=People $\& l v l=$ Data\&show $=$ html $\&$ dasid $=613$

The original objective of the Cretan Shelf dataset was to unravel the structure of the benthic ecosystem of the continental shelf of Crete; the macrofauna of Greek polluted sites gathered data on the benthic effects of fish farming (Karakassis \& Eleftheriou 1997, 1998, Karakassis et al. 1999, 2000, 2002, Karakassis \& Hatziyanni 2000, Hyland et al. 2005). Dataset code: ka.

Kendall M.A., 1996: Arctic soft-sediment macrobenthos. Plymouth Marine Laboratory, UK.

Available at: www.marbef.org/modules.php?name=People $\& l v l=$ Data \&show $=$ html\&dasid $=533$

Samples of the macrobenthic fauna of soft sediments were collected from around Svalbard during the 1991 Arctic EPOS 
Appendix 1. (continued)

cruise of RV Polarstern (Kendall 1995). Dataset code: ar.

Kendall M.A., Widdicombe S., 1999: Plymouth Sound dataset. Soft sediment macrobenthos from the Plymouth Sound from 1995. Plymouth Marine Laboratory, UK. Available at: www.marbef.org/modules.php?name=People\&lvl=Data\&sh ow $=$ html \&dasid $=534$

The intended use of this dataset of the Plymouth Sound was the description of small-scale spatial patterns in soft sediment fauna (Kendall \& Widdicombe 1999). Dataset code: pl.

Kotwicki L., 1996: Bay of Puck dataset. Polish Academy of Sciences, Institute of Oceanology, Department of Marine Ecology, Poland.

Available at: www.marbef.org/modules.php?name=People $\& l v l=$ Data $\&$ show $=$ html $\&$ dasid $=611$

The dataset was collected in July 1996 for habitat mapping of the Bay of Puck. Dataset code: pu.

Koukouras A., 2000: Northern Aegean dataset. Aristotelian University of Thessaloniki Department of Zoology and Zoological Museum, School of Biology, Greece.

Available at: www.marbef.org/modules.php?name=People $\& l v l=$ Data\&show $=$ html $\&$ dasid $=630$

The dataset consists of a museum collection of long term qualitative macrobenthic data from the Aegean and Ionian Sea. An extensive list of peer-reviewed articles was derived from this dataset. Dataset code: 01 .

Mackie A.S.Y., Oliver P.G., Rees E.I.S., 1991: Biomôr 1 dataset. Benthic data from the Southern Irish Sea from 19891991. National Museum and galleries of Wales, Cardiff, UK. Available at: www.marbef.org/modules.php?name=People $\& l v l=D a t a \&$ show $=$ html $\&$ dasid $=1600$

Surveys of benthic invertebrates of the Southern Irish Sea were carried out in 1989 and 1991. Both quantitative and qualitative samples were taken for faunal and sediment analysis (Mackie et al. 1995). Dataset code: o5.

Nevrova H., Petrov A., Revkov N., 1996: Laspibay-Black Sea dataset-IBSS, Sevastopol. Institute of Biology of the Southern Seas (IBSS), Ukraine.

Available at: www.marbef.org/modules.php?name=People $\& l v l=$ Data\&show $=$ html \&dasid= 629

The dataset arose from an investigation of the structure of macrozoobenthos and microphytobenthos assemblages in relation to recreation and marifarming development in Laspi Bay (SW Crimea, the Black Sea) (Petrov 2000, Revkov \& Nikolaenko 2002, Revkov 2003a,b, Revkov \& Sergeeva 2004). Dataset code: m9.

Occhipinti-Ambrogi A., 2002: Cesenatico dataset. Department of Ecologia del Territorio, University of Pavia, Italy.

Available at: www.marbef.org/modules.php?name=People $\& l v l=$ Data\&show $=$ html $\&$ dasid $=600$

This dataset was compiled in order to monitor long-term responses of the macrobenthos community to environmental quality changes in the Northern Adriatic Sea (OcchipintiAmbrogi et al. 2005). Dataset code: oc.

Olsgard F., 1994: Oslofjord 93-94. Akvaplan-niva, Norway. Available at: www.marbef.org/modules.php?name=People $\& l v l=$ Data $\&$ show $=$ html $\&$ dasid $=1152$

Unpublished data collected as part of a general environmental investigation of the Oslofjord. Dataset code: of.

Petrov A., Revkov N., 1986: MegFeod-Black Sea datasetIBSS, Sevastopol. Institute of Biology of the Southern Seas
(IBSS), Ukraine.

Available at: www.marbef.org/modules.php?name=People $\& l v l=$ Data $\&$ show $=$ html $\&$ dasid $=626$

The dataset arose from a comparative investigation of the structure and spatial patterns of macrozoobenthic assemblages along the coast of southeastern Crimea (Sergeeva \& Mikhailova 1989a, Mironov et al. 1992, Petrov 1999, 2000, Hyland et al. 2005). Dataset code: m1.

Petrov A., Revkov N., 1993: Strelbay-Black Sea datasetIBSS, Sevastopol. Institute of Biology of the Southern Seas (IBSS), Ukraine.

Available at: www.marbef.org/modules.php?name=People $\& l v l=$ Data $\&$ showf $=$ html $\&$ dasid $=627$

The dataset arose from an investigation of the structure and condition of macrozoobenthos assemblages under persistent anthropogenic impact (Kisseleva et al. 1999, Petrov 2000, Revkov 2003a,b, Petrov \& Revkov 2003, 2005). Dataset code: m4.

Petrov A., Revkov N., 1986: Jalta-Black Sea dataset - IBSS, Sevastopol. Institute of Biology of the Southern Seas (IBSS), Ukraine.

Available at: www.marbef.org/modules.php?name=People $\& l v l=$ Data\&show $=$ html $\&$ dasid $=628$

The dataset arose from comparative studies of the condition of macro- and meio-zoobenthos around Jalta Gulf under the influence of domestic sewage discharge and recreation activity (Sergeeva 1992, Mikhailova 1989, Petrov 1999, 2000). Dataset code: m5.

Picton B.E., Emblow C.S., Morrow C.C., Sides E.M., Tierney P., McGrath D., McGeough G., McCrea M., Dinneen P., Falvey J., Dempsey S., Dowse J., Costello M.J., 1999: Marine sites, habitats and species data collected during the BioMar survey of Ireland. Environmental Sciences Unit, Trinity College, Dublin, Ireland.

Available at: www.marbef.org/modules.php?name=People $\& l v l=$ Data $\&$ show $=$ html $\&$ dasid $=345$

Through marine habitat and biotope surveys, the Biomar project (1992-1996) aimed at improved management of coastal ecosystems in Britain and Northern Ireland. Qualitative benthic data from 200 littoral and 700 sublittoral sites around the Republic of Ireland were collected both by direct observations on seashores and by SCUBA divers (Sides et al. 1995, Costello et al. 1996, Connor et al. 1999, McGrath et al. 2000). Dataset code: bi.

Rumohr H., 1995: Kiel Bay intercalibration dataset. Leibniz Institute of Marine Sciences, Marine Ecology Division, Germany.

Available at: www.marbef.org/modules.php?name=People $\& l v l=$ Data $\&$ show $=$ html $\&$ dasid $=618$

The ICES/HELCOM Intercalibration Exercise provided a series of replicate samples from 1 station in Kiel Bay from May 1995 (Rumohr et al. 2001). Dataset code: 70.

Rumohr H., Fleischer D., 2004: N3 data of Kiel Bay. Leibniz Institute of Marine Sciences, Marine Ecology Division, Germany.

Available at: www.marbef.org/modules.php?name=People $\& l v l=$ Data $\&$ show $=$ html $\&$ dasid $=617$

Long term monitoring of all invertebrate species of station N3 in Kiel Bay in the Western Baltic was conducted between 1986 and 2004. Dataset code: n3.

Sardá R., 1997: Soft Bottom Communities of the Bay of 
Appendix 1. (continued)

Blanes. Centre d'Estudis Avançats de Blanes (CEAB) Consejo Superior de Investigaciones Científica (CSIC), Spain. Available at: www.marbef.org/modules.php?name=People $\&$ lvl=Data $\&$ show $=$ html $\&$ dasid $=603$

Soft bottom communities of the Bay of Blanes in Girona were sampled from 1992 to 1997 in the framework of 2 Spanish national projects analysing the regulation of biological production in the Mediterranean littoral (Pinedo et al. 1996, 1997, Sarda et al. 1999, 2000). Dataset code: bl.

The Norwegian Oil Industry Association, 2001: Offshore reference stations, North/Norwegian sea. The Norwegian Oil Industry Association (OLF), Akvaplan-niva and Det Norske Veritas, Norway.

Available at: www.marbef.org/modules.php?name=People $\& l v l=$ Data $\&$ show $=$ html $\&$ dasid $=999$

The dataset is a compilation of selected reference stations from large-scale annual surveys of the benthic fauna in the vicinity of petroleum installations, funded by the Norwegian Oil Industry Association. Dataset code: o3.

The Norwegian Oil Industry Association, 2002: Offshore reference stations, Norwegian/Barents Sea. The Norwegian Oil Industry Association (OLF), Akvaplan-niva and Det Norske Veritas, Norway.

Available at: www.marbef.org/modules.php?name=People $\& l v l=$ Data $\&$ show $=$ html $\&$ dasid $=997$

Compilation of selected reference stations from large-scale annual surveys of the benthic fauna in the vicinity of petroleum installations, funded by the Norwegian Oil Industry Association. Dataset code: 04 .

The Norwegian Oil Industry Association, 2000: Offshore reference stations, Finnmark. The Norwegian Oil Industry Association (OLF), Akvaplan-niva and Det Norske Veritas, Norway.

Available at: www.marbef.org/modules.php?name=People $\& l v l=$ Data $\&$ show $=\mathrm{html} \&$ dasid $=998$

Compilation of selected reference stations from large-scale annual surveys of the benthic fauna in the vicinity of petroleum installations, funded by the Norwegian Oil Industry Association. Dataset code: o6.

Vatova A., 1936: Fauna Bentonica dataset, Instituto di Biologia Marine per l'Adriatico, Venezia, Italy.

Available at: www.marbef.org/modules.php?name=People $\& l v l=$ Data\&show $=$ html $\&$ dasid $=596$

These data were collected between 1934 and 1936 as part of a PhD study. Scientists from the Hellenic Centre for Marine Research computed the dataset afterwards (Vatova 1949). Dataset code: $f b$.

Wesławski J.M., Malec E., Jaskuła R., Włodarska-Kowalczuk M., Kędra M., 2002: Polish Arctic Marine Programme. Macrobenthic data from Hornsund from 2002. Polish Academy of Sciences, Institute of Oceanology, Poland.

Available at: www.marbef.org/modules.php?name=People $\& l v l=$ Data $\&$ show $=$ html $\&$ dasid $=243$

This dataset was collected as part of an All Taxa Biodiversity Inventory (ATBI). Dataset code: hs.

Whomersley P., 2003: National Marine Monitoring Programme. Benthos data of the North Sea, Irish Sea, English Channel from 2002-2003. Centre for environment, fisheries and aquaculture science, Burnham-on-Crouch, UK.
Available at: www.marbef.org/modules.php?name=People $\& l v l=$ Data\&show $=$ html\&dasid $=615$

The data were generated as part of the UK's mandatory monitoring requirements under the OSPAR Joint Assessment and Monitoring Programme (JAMP) and to monitor long-term trends at selected temporal stations around the UK. Dataset code: $n p$.

Zenetos A., 1986: Zoobenthos Kyklades, Aegean Sea dataset. Hellenic Centre for Marine Research, Greece.

Available at: www.marbef.org/modules.php?name=People $\& l v l=$ Data $\&$ show $=$ html $\&$ dasid $=625$

Under the framework of the project 'Oceanographic studies in open Seas', a survey of the benthic fauna of the Central Aegean Sea was performed in July 1986 (Van Aartsen \& Zenetos 1987, Zenetos et al. 1991, 1993, Kallonas et al. 1999). Dataset code: $m 8$.

Zenetos A., 1987: Aegean Sea coastal benthic communities, Geras Gulf (Mytilini), chemical pollution (tannery effluents). Hellenic Centre for Marine Research, Greece.

Available at: www.marbef.org/modules.php?name=People $\& l v l=$ Data $\&$ show $=$ html $\&$ dasid $=622$

An impact study of a tannery effluent on the benthic community was conducted over 2 and a half years in the Geras Gulf (Papathanassiou et al. 1989, Zenetos \& Papathanassiou 1989, Pancucci \& Zenetos 1990, Zenetos et al. 1992, Papathanassiou \& Zenetos 1993, Bogdanos et al. 2002). Dataset code: $m 2$.

Zenetos A., 1990: Seasonal zoobenthos, Saronikos. Hellenic Centre for Marine Research, Greece.

Available at: www.marbef.org/modules.php?name=People $\& l v l=$ Data $\&$ show $=$ html\&dasid $=289$

This dataset was collected under the framework of 2 different projects, recording biological parameters and an investigation of the effects of a wastewater treatment plant on the zoobenthos in Saronikos Gulf. (Nicolaidou et al. 1993, Zenetos et al. 1994, 1999, Simboura et al. 1995, Simboura \& Zenetos 2002). Dataset code: $\mathrm{m3}$.

Zenetos A., 1991: Kalamitsi dataset. Hellenic Centre for Marine Research, Greece.

Available at: www.marbef.org/modules.php?name=People $\& l v l=$ Data\&show $=$ html\&dasid= 623

The dataset arose from a survey of the Kalamitsi area of the Ionian Sea (Zenetos et al. 1997). Dataset code: m6.

Zenetos A., Bogdanos C., 1992: Kerkyra dataset. Hellenic Centre for Marine Research, Greece.

Available at: www.marbef.org/modules.php?name=People $\& l v l=$ Data\&show $=$ html\&dasid $=624$

The dataset arose from a survey of the Kerkyra area of the Ionian Sea. Dataset code: $m 7$.

Zettler M.L., 2005: Macrozoobenthos Baltic Sea (1980-2005) as part of the IOW-Monitoring. Institut für Ostseeforschung Warnemünde, Germany.

Available at: www.marbef.org/modules.php?name=People $\& l v l=$ Data $\&$ show $=$ html $\&$ dasid $=601$

This time-series study of species composition and biomass or abundance of macrozoobenthos in the Belt Sea and the Baltic proper provide data from 1979 to 2005 as part of the HELCOM monitoring programme (Wasmund et al. 2004). Dataset code: ze. 